\title{
Two-membered mixed cultures of methanogenic and aerobic bacteria in $\mathrm{O}_{2}$-limited chemostats
}

\author{
JAN GERRITSE* and JAN C. GotTSCHAL \\ Department of Microbiology, University of Groningen, Kerklaan 30, 9751 NN Haren, The Netherlands
}

(Received 12 February 1993; accepted 9 March 1993)

\begin{abstract}
Three different co-cultures composed of a methanogenic and a strictly aerobic bacterium were grown under $\mathrm{O}_{2}$ limitation in continuous cultures. The combinations used were (1) Methanobacterium formicicum with the aerobic heterotroph Comamonas testosteroni; (2) M. formicicum with a methanotrophic Methylocystis species; and (3) Methanosarcina barkeri with C. testosteroni. Although true steady-states were not obtained, growth and metabolic activity of the methanogenic and aerobic organisms occurred during $\mathrm{O}_{2}$-limited growth of these mixed cultures over extended periods of time. Co-cultures with $C$. testosteroni were considerably more stable than those with Methylocystis. Co-cultures with $M$. barkeri were less $\mathrm{O}_{2}$-sensitive than those with $M$. formicicum. C. testosteroni exhibited a higher $\mathrm{O}_{2}$-affinity than Methylocystis, resulting in a lower dissolved oxygen tension and a superior protection of the methanogenic bacteria against $\mathrm{O}_{2}$-poisoning than in mixed cultures with Methylocystis. The dissolved $\mathrm{O}_{2}$-concentrations in the mixed cultures were below the detection limit of the $\mathrm{O}_{2}$-probes used $(0 \cdot 2 \mu \mathrm{M})$. Calculations based on growth properties of pure cultures of $C$. testosteroni, M. barkeri and M. formicicum suggested that the dissolved $\mathrm{O}_{2}$-concentrations in the mixed cultures, as well as the $\mathrm{O}_{2}$-inhibition constants (apparent $K_{1}^{\mathrm{O}_{2}}$ ) of the methanogens were in the nanomolar range.
\end{abstract}

\section{Introduction}

Methanogenic bacteria are extremely sensitive to $\mathrm{O}_{2}$. They contain high concentrations of $\mathrm{O}_{2}$-labile compounds and require a relatively low redox potential for growth (Mah \& Smith, 1981; Morris, 1976; Vogels et al., 1988). Although methanogens may possess some enzymic self-defence against $\mathrm{O}_{2}$-toxicity, growth in pure cultures is completely blocked in the presence of $\mathrm{O}_{2}$ (Jones et al., 1983; Kengen et al., 1991; Kiener et al., 1988; Kiener \& Leisinger, 1983; Kirby et al., 1981; Patel et al., 1984; Roberton \& Wolfe, 1970; Smith \& Hungate, 1958; Zehnder \& Wuhrmann, 1977). Accordingly, the typical natural habitats of methanogens are environments containing relatively large anoxic areas, such as aquatic sediments, flooded soils, landfills, stratified waters and the intestinal tract of animals. In addition, they may abide in anoxic micro-niches established in predominantly oxic environments in nutrient-rich 'oases', such as detritus aggregates or faecal pellets (Alldredge \& Cohen, 1987; Lloyd et al., 1986; Oremland, 1988; Sieburth, 1987). In these habitats, methanogenic bacteria

*Author for correspondence. Tel. 3150632169 ; fax 3150632154. are protected from $\mathrm{O}_{2}$-damage by the high respiratory activity of aerobic (micro-) organisms.

Near oxic/anoxic interfaces, particularly in systems with very steep $\mathrm{O}_{2}$-gradients, methanogenic bacteria can live very closely to strictly aerobic bacteria. Metabolic coupling of anaerobes and aerobes may occur through exchange of metabolites (Wimpenny, 1981). An illustrative example is the methane cycle in freshwater environments characterized by the production of methane by strictly anaerobic methanogenic bacteria within the anoxic zone of the sediment or the water column and the oxidation of methane by strictly aerobic methanotrophic bacteria located in a narrow zone at the oxic/anoxic interface where the diffusion profiles of methane and $\mathrm{O}_{2}$ overlap (Rudd \& Taylor, 1980).

Several methanogenic bacteria - Methanococcus maripaludis, Methanosarcina barkeri, Methanobacterium thermoautotrophicum, Methanobacterium bryantii and Methanobrevibacter arboriphilus - though metabolically inactive, have been shown to survive oxic periods quite well (Jones et al., 1983; Kiener et al., 1988; Kiener \& Leisinger, 1983; Patel et al., 1983; Roberton \& Wolfe, 1970; Zehnder \& Wuhrmann, 1977). Hence, it can be anticipated that in areas exposed to alternating oxic/anoxic conditions the microbial population can 
contain methanogens as well as strict aerobes, though their activity is separated in time, depending on the (temporal) presence or absence of $\mathrm{O}_{2}$.

In spite of their apparent mutually exclusive type of metabolism, there are some indications that methanogenic and aerobic bacteria may also share the same micro-habitat (growth without separation in time and/or in space). This paradox may be explained by the fact that under $\mathrm{O}_{2}$-limitation aerobic respiring micro-organisms can maintain such very low dissolved $\mathrm{O}_{2}$-concentrations that complete inhibition of methanogens is avoided (Scott et al., 1985; Lloyd et al., 1989; Gerritse et al., 1990).

Co-existence of strictly anaerobic and aerobic bacteria is interesting because it facilitates interspecific microbial interactions including substrate competition, cross-feeding and co-operation during the degradation of organic matter. Defined laboratory cultures have been used successfully in revealing information on the co-existence of and interactions between such metabolically diverse organisms (Chapman et al., 1992; Gerritse et al., 1990, 1992; Gottschal \& Szewzyk, 1985; Ohta et al., 1990; Van der Hoeven \& Gottschal, 1989; Wimpenny \& Abdollahi, 1991). However, the anaerobic bacteria used thus far in mixed cultures with aerobes are Desulfovibrio, Streptococcus, Clostridium and Veillonella species, all of which are known to tolerate low concentrations of $\mathrm{O}_{2}$.

The aims of the present study were to investigate whether methanogenic bacteria, renowned for their very high sensitivity to $\mathrm{O}_{2}$, can also grow in defined mixed cultures with strict aerobes. In addition, such cultures may also provide quantitative information on the factors responsible for the very narrow range of $\mathrm{O}_{2}$-concentrations which may allow co-existence of such bacteria. To this end, growth of the methanogens Methanobacterium formicicum and Methanosarcina barkeri, and the aerobes Comamonas testosteroni and Methylocystis sp. was studied both in pure cultures and in mixed cultures in the presence of growth-limiting concentrations of $\mathrm{O}_{2}$.

\section{Methods}

Organisms. Methanobacterium formicicum strain Wolfe was isolated and identified at the Department of Microbiology of the University of Nijmegen, The Netherlands, and kindly supplied by Dr E. RaemakersFranken. Methanosarcina barkeri DSM 800 is maintained in the strain collection of our laboratory. The methanotrophic bacterium Methylocystis sp. strain T-1 was obtained from Dr K. Takeda, who isolated this organism from a soil which leaked methane gas (Takeda, 1988). Comamonas testosteroni sp., was isolated in our laboratory and described previously (Gerritse et al., 1990).

Media and growth conditions. The medium used was a modified version of that described by Zehnder and Wuhrmann (1977). Basal medium contained (values in $\mathrm{g} \mathrm{l}^{-1}$ ): $\mathrm{KH}_{2} \mathrm{PO}_{4}, 0.54 ; \mathrm{Na}_{2} \mathrm{HPO}_{4}, 1.34$; $\mathrm{NH}_{4} \mathrm{Cl}, 0.3 ; \mathrm{NaCl}, 0.3 ; \mathrm{CaCl}_{2} .2 \mathrm{H}_{2} \mathrm{O}, 0.04 ; \mathrm{MgCl}_{2} .6 \mathrm{H}_{2} \mathrm{O}, 0.04$;
Nitriloacetic acid (trisodium salt), $0.02 ; \mathrm{FeCl}_{2} .4 \mathrm{H}_{2} \mathrm{O}, 0.01 ; \mathrm{KAl}\left(\mathrm{SO}_{4}\right)_{2}$, $0.0001 ; \quad \mathrm{Na}_{2} \mathrm{SeO}_{3} .5 \mathrm{H}_{2} \mathrm{O}, \quad 0.00003 ; \quad \mathrm{Na}_{2} \mathrm{WO}_{4} .2 \mathrm{H}_{2} \mathrm{O}, \quad 0.00003 ;$ $\mathrm{ZnSO}_{4} .7 \mathrm{H}_{2} \mathrm{O}, 0.0001 ; \mathrm{MnCl}_{2} .4 \mathrm{H}_{2} \mathrm{O}, 0.00003 ; \mathrm{H}_{3} \mathrm{BO}_{3}, 0.0003 ;$ $\mathrm{CoCl}_{2} .6 \mathrm{H}_{2} \mathrm{O}, 0.0002 ; \mathrm{CuCl}_{2} .2 \mathrm{H}_{2} \mathrm{O}, 0.00001 ; \mathrm{NiCl}_{2} .6 \mathrm{H}_{2} \mathrm{O}, 0.00002$; $\mathrm{Na}_{2} \mathrm{MoO}_{4} .2 \mathrm{H}_{2} \mathrm{O}, 0.00003$; resazurin, 0.001; yeast extract (BBL) 0.1 ; gelysate peptone (BBL) 0.1 ; and $1 \mathrm{ml} \mathrm{l}^{-1}$ of a filter-sterilized $(0.2 \mu \mathrm{m}$ pore-size) vitamin solution according to Heijthuisen \& Hansen (1986).

For oxic batch cultures of Methylocystis and C. testosteroni the basal medium was supplemented with $0.2 \mathrm{~g} \mathrm{Na}_{2} \mathrm{SO}_{4} \mathrm{l}^{-1}$. Potassium-L-lactate (20 mM) was added as the carbon and energy source for C. testosteroni, whereas methanol $(50-100 \mathrm{~mm})$ or methane $(50 \%, \mathrm{v} / \mathrm{v}$, in the gasphase) were provided for growth of Methylocystis.

Methanogenic bacteria were routinely maintained in anoxic batch cultures with medium amended with $\mathrm{NaHCO}_{3}(30 \mathrm{~mm})$ and volatile organic acids (1.2 mM-acetate, $0.4 \mathrm{~mm}$-propionate, $0.2 \mathrm{~mm}$-butyrate, $0.05 \mathrm{~mm}$-2-methylbutyrate, $0.05 \mathrm{~mm}$-isobutyrate, $0.05 \mathrm{~mm}$-valerate and $0.05 \mathrm{~mm}$-isovalerate). Anoxic media were prepared under a $\mathrm{N}_{2} / \mathrm{CO}_{2}$ $(80: 20, v / v)$ atmosphere in culture bottles or Hungate tubes sealed with butyl-rubber stoppers and reduced with $10 \mathrm{ml} \mathrm{l}^{-1}$ of a $(1.25 \%, \mathrm{w} / \mathrm{v})$ $\mathrm{Na}_{2} \mathrm{~S} .9 \mathrm{H}_{2} \mathrm{O} /$ cysteine. $\mathrm{HCl}$ mixture. Sodium formate $(100 \mathrm{mM})$ was supplied as the carbon and energy source for $M$. formicicum from a separately autoclaved stock solution. For growth of $M$. barkeri, the $\mathrm{NaCl}$ concentration of the medium was raised to $0.6 \mathrm{~g} \mathrm{l}^{-1}$ and methanol $(100-150 \mathrm{~mm})$ was added from an autoclaved $(50 \%, \mathrm{v} / \mathrm{v})$ stock solution.

Chemostat media were the same as those used for batch cultures of methanogenic bacteria with the exception that the sulphide/cysteine solution was replaced by $10 \mathrm{ml} \mathrm{l}^{-1}$ of a thiosulphate/cysteine solution (pH 10) containing $5 \%(\mathrm{w} / \mathrm{v}) \mathrm{Na}_{2} \mathrm{~S}_{2} \mathrm{O}_{3} .5 \mathrm{H}_{2} \mathrm{O}$ and $1.25 \%(\mathrm{w} / \mathrm{v})$ cysteine. $\mathrm{HCl}$. For chemostat cultures with $M$. formicicum, peptone was omitted and the yeast extract concentration was increased from $0 \cdot 1$ to $1 \mathrm{~g} \mathrm{l}^{-1}$. Formic acid was pumped from a concentrated solution into the culture vessel, resulting in a reservoir concentration $\left(S_{\mathrm{r}}\right)$ of $430-460 \mathrm{~mm}$.

Chemostat culture vessels had a liquid volume of $400-500 \mathrm{ml}$ and were equipped with sensors enabling continuous measurement and regulation of temperature, redox potential and $\mathrm{pH}$. Stable measurement of dissolved $\mathrm{O}_{2}$ with Ingold sensors over extended periods of time (several weeks) was not possible as these electrodes appeared to be poisoned in the reduced chemostat media. $\mathrm{O}_{2}$-concentrations in the gas phase were measured with a Servomex 1100 oxygen analyser. A description of the chemostat configuration was published previously (Gerritse et al., 1990).

Chemostat cultures of $M$. formicicum were grown at $37^{\circ} \mathrm{C}$ and pH 7.5, whereas for cultures with $M$. barkeri the temperature was $35^{\circ} \mathrm{C}$ and the $\mathrm{pH}$ 6.9. The $\mathrm{pH}$ was maintained by automatic titration with $1 \mathrm{M}-\mathrm{NaOH}$ or $1 \mathrm{M}-\mathrm{HCl}$. The chemostats were stirred by means of a magnetic stirrer and the head-space of the culture vessel was gassed with $\mathrm{N}_{2} / \mathrm{CO}_{2}$ gas (80:20, v/v), freed of traces of $\mathrm{O}_{2}$ by passing over hot copper turnings. For $\mathrm{O}_{2}$-limited growth, air was mixed with the $\mathrm{N}_{2} / \mathrm{CO}_{2}$ flow-gas resulting in mixtures containing $0-2 \%(\mathrm{v} / \mathrm{v}) \mathrm{O}_{2}$, which were supplied both via the head-space as well as via a submerged pipe into the culture liquid.

Cultures of $M$. formicicum had some tendency to adhere to the glass and electrodes present in the chemostat $(<10 \%$ of the total biomass in the culture). In cultures with $M$. formicicum, wall-growth was removed before co-culture experiments with aerobic bacteria were performed. Wall-growth was not observed in cultures of $M$. barkeri.

Cell quantification in mixed cultures. The biomass of the populations of individual species in mixed chemostat cultures was estimated by combining cell-carbon measurements and microscopic cell-counts. Cells of $M$. barkeri (large aggregated cocci), $M$. formicicum (long thin rods to filaments), $C$. testosteroni (thick straight rods) and Methylocystis (small oval rods) could readily be distinguished morphologically. The 
ratio between cell-numbers of different species in mixed cultures was determined on a Carl Zeiss G42-110-e phase-contrast microscope in samples taken from continuous cultures, fixed with $0.4 \%$ formaldehyde. Numbers of bacterial cells per unit volume were obtained with a Bürker-Türk counting chamber. After appropriate dilution, $500-1500$ cells were counted in at least duplicate samples. In aggregates of cells, individual cells were distinguished on the basis of a microscopically visible cell-wall. Subsequently, the amount of cellcarbon of the individual bacteria in the mixed cultures was calculated from the total cell-carbon concentration in the co-cultures and a cellnumber/cell-carbon calibration determined in pure cultures. Cell counts in batch cultures of $M$. formicicum, M. barkeri, C. testosteroni and Methylocystis yielded values of $6.90 \times 10^{9}, 0.268 \times 10^{9}, 5.71 \times 10^{9}$ and $13 \cdot 10 \times 10^{9}$ cells (mg cell-carbon) $)^{-1}$, respectively.

Respirometry. $\mathrm{O}_{2}$-consumption rates were determined at $37^{\circ} \mathrm{C}$ (Methylocystis) or $35^{\circ} \mathrm{C}$ (C. testoteroni) in a Yellow-Springs-type biological oxygen monitor equipped with a polarographic oxygen electrode connected to a Keithley model 485 picoamperometer for increased sensitivity at very low $\mathrm{O}_{2}$-concentrations (Gerritse et al., 1992). This method allowed detection of $\mathrm{O}_{2}$ at concentrations $>0.01 \mu \mathrm{M} . \mathrm{O}_{2}$-consumption of $C$. testosteroni was analysed with dilute resting cell suspensions in medium containing chloramphenicol and 20 mM-L-lactate. To anoxic cell-suspensions of $C$. testosteroni, $\mathrm{O}_{2}$ was added to a concentration of about $10 \mu \mathrm{M}$ by injection of air-saturated water. $\mathrm{O}_{2}$-utilization by Methylocystis was analysed with resting cell suspensions saturated with an air/methane mixture (about $50 \%, \mathrm{v} / \mathrm{v}$ ) or in air-saturated suspensions containing $50 \mathrm{~mm}$-methanol. Kinetic constants, apparent $K_{\mathrm{m}}{ }^{\mathrm{O}_{2}}$ and $Q_{\mathrm{O}_{2}}^{\max }$, values, were obtained from direct linear plots. It was assumed that air-saturated suspensions contained $218 \mu \mathrm{M}$ dissolved $\mathrm{O}_{2}$.

Determination of growth kinetics. Maximum specific growth rates ( $\mu_{\max }$ values) were determined by following the change in optical density at $660 \mathrm{~nm}\left(\mathrm{OD}_{660}\right)$ in batch cultures, or in continuous cultures with the dilution $(D)$ rate $20-50 \%$ above the $\mu_{\max }$ (wash-out experiments). Half-saturation constants for growth $\left(K_{\mathrm{s}}\right)$ were obtained from specific growth rates and residual formate or methanol concentrations $(\vec{s})$ in steady-state cultures of $M$. formicicum or $M$. barkeri, respectively. It was assumed that growth of these bacteria followed Monod-type kinetics and the corresponding $K_{\mathrm{s}}$ values were estimated from direct linear plots.

Analytical procedures. Quantification of gases $\left(\mathrm{CH}_{4}, \mathrm{CO}_{2}\right.$ and $\left.\mathrm{O}_{2}\right)$, total organic carbon and cell-carbon was done as described previously (Gerritse et al., 1990). Formate concentrations were determined colorimetrically according to the method of Lang \& Lang (1972). LLactate concentrations were determined gas-chromatographically as described by Nanninga \& Gottschal (1985). Methanol was measured on a Packard 427 gas-chromatograph equipped with a Porapack $\mathbf{R}$ column $\left(80 / 100\right.$ mesh) kept at a temperature of $114^{\circ} \mathrm{C}$. The temperature of the injector and the (flame-ionization) detector was $120^{\circ} \mathrm{C}$.

Chemicals. All chemicals used were of analytical grade quality and obtained from commercial companies, except L-lactic acid (Fluka), which contained $90 \% \mathrm{~L}$-lactic acid in water.

\section{Results}

Growth and $\mathrm{O}_{2}$-uptake kinetics of pure cultures of Comamonas testosteroni and Methylocystis sp.

Maximum specific-consumption rates $\left(Q_{\mathrm{O}_{2}}^{\max }\right)$ and halfsaturation constants (apparent $K_{\mathrm{m}}$ ) for $\mathrm{O}_{2}$ were obtained respirometrically with cell-suspensions of Methylocystis and $C$. testosteroni, grown separately in oxic batch cultures.

The maximum specific growth rate $\left(\mu_{\max }\right)$ of $C$. testosteroni in a batch culture at $35^{\circ} \mathrm{C}$ on $20 \mathrm{mM}-\mathrm{L}-$ lactate was $0.39( \pm 0.02) \mathrm{h}^{-1}$. Rates of $\mathrm{O}_{2}$-consumption by resting cell suspensions of $C$. testosteroni revealed a $Q_{\mathrm{O}_{2}}^{\max }$ of $22.4 \mu \mathrm{mol}$ (mg cell-carbon) $)^{-1} \mathrm{~h}^{-1}$ and an apparent $K_{\mathrm{m}}$ of $0.45 \mu \mathrm{M}$ (Table 1). Cell suspensions of $C$. testosteroni did not oxidize methane or methanol.

In a shake culture $\left(150\right.$ r.p.m.) at $37^{\circ} \mathrm{C}$ with an air/methane mixture $(50: 50, \mathrm{v} / \mathrm{v})$ in the head-space, Methylocystis grew with a $\mu_{\max }$ of $0.09 \mathrm{~h}^{-1}$. When the carbon and energy source of an exponential-phase culture of Methylocystis was switched from methane to methanol $(100 \%$ air in the head-space and addition of $60 \mathrm{mM}$-methanol), exponential growth continued without a lag at a rate of $0.08 \mathrm{~h}^{-1}$. Methane-grown cells of Methylocystis oxidized methane as well as methanol. The affinity for $\mathrm{O}_{2}$ was considerably higher with methanol than with methane as the substrate (Table 1).

\section{Growth of Methanobacterium formicicum and Methanosarcina barkeri in anoxic continuous cultures}

Some growth parameters of $M$. formicicum and $M$. barkeri were determined in continuous cultures with formate or methanol, respectively, as the growth substrates.

Determination of $\mu_{\max }$ through wash-out experiments using anoxic steady-state cultures of $M$. formicicum $(D=$ $0.026 \mathrm{~h}^{-1}, \mathrm{pH} 7.5$, temperature $37^{\circ} \mathrm{C}$ ) revealed relatively low values. Cell-yield values and the $K_{\mathrm{s}}$ for formate were also measured in this steady-state culture (Table 2). In batch culture on $100 \mathrm{~mm}$-formate similar growth rate $\left(\mu_{\max }=0.028 \mathrm{~h}^{-1}\right)$ and yield data $\left(0.15 \mathrm{~g} \mathrm{~mol}^{-1}\right)$ were obtained.

With $M$. barkeri, methanol-limited steady-state cultures $\left(D=0.026 \mathrm{~h}^{-1}, \mathrm{pH} 6.9\right.$, temperature $\left.35^{\circ} \mathrm{C}\right)$ were obtained (Table 2). At a dilution rate of $0.05 \mathrm{~h}^{-1} M$. barkeri washed-out at a rate which indicated a $\mu_{\max }$ of $0.042 \mathrm{~h}^{-1}$, very close to that found in batch culture $\left(0.045 \mathrm{~h}^{-1}\right)$.

The stoichiometries of methane production observed in the present study (Table 2) agreed well with the known equations for the methanogenic conversion of formate and methanol reported previously (Vogels et al., 1988).

$$
\text { M. formicicum: } 4 \mathrm{HCOO}^{-}+4 \mathrm{H}^{+} \rightarrow \mathrm{CH}_{4}+3 \mathrm{CO}_{2}+2 \mathrm{H}_{2} \mathrm{O}
$$

$$
\text { M. barkeri: } 4 \mathrm{CH}_{3} \mathrm{OH} \rightarrow 3 \mathrm{CH}_{4}+\mathrm{CO}_{2}+2 \mathrm{H}_{2} \mathrm{O}
$$

Washed cell-suspensions from chemostat cultures of $M$. formicicum or $M$. barkeri did not consume measur- 
Table 1. Kinetic parameters for $\mathrm{O}_{2}$-consumption by resting cells of Comamonas testosteroni and Methylocystis sp. pre-grown on L-lactate or methane, respectively

Values are means of at least three determinations \pm standard deviation.

\begin{tabular}{llccc}
\hline \hline Species & $\begin{array}{l}\text { Substrate } \\
\text { oxidized }\end{array}$ & $\begin{array}{c}Q_{\mathrm{O}_{2}}^{\max } \\
\left(\mu \mathrm{mol} \mathrm{mg} \mathrm{h}^{-1}\right)\end{array}$ & $\begin{array}{c}\text { Apparent } K_{\mathrm{m}}^{\mathrm{O}_{2}} \\
(\mu \mathrm{M})\end{array}$ & $Q_{\mathrm{O}_{2}}^{\max } / K_{\mathrm{m}}^{\mathrm{O}_{2}}$ \\
\hline C. testosteroni & L-Lactate & $22.4 \pm 4 \cdot 7$ & $0.45 \pm 0.14$ & $49 \cdot 8$ \\
Methylocystis & Methane & $7 \cdot 4 \pm 0 \cdot 2$ & $4.7 \pm 0.75$ & 1.6 \\
& Methanol & $18.6 \pm 0.3$ & $1.9 \pm 0.37$ & $9 \cdot 8$ \\
\hline
\end{tabular}

Table 2. Growth parameters obtained from steady-state cultures of Methanobacterium formicicum and Methanosarcina barkeri

The dilution rate of the steady-state cultures was $0.026 \mathrm{~h}^{-1}$.

\begin{tabular}{cccccccc}
\hline \hline Species & $\begin{array}{l}\text { Substrate } \\
(\mathrm{mM} \text { in } \\
\text { reservoir) }\end{array}$ & $\begin{array}{c}Q_{\text {substrate }} \\
\left(\mathrm{mmol} \mathrm{g}^{-1} \mathrm{~h}^{-1}\right)\end{array}$ & $Q_{\mathrm{CH}_{4}}$ & $\begin{array}{c}Y_{\text {substrate }} \\
\left(\mathrm{g} \mathrm{mol}^{-1}\right)\end{array}$ & $\begin{array}{c}\bar{s}_{\text {substrate }} \\
(\mathrm{mM})\end{array}$ & $\begin{array}{c}\mu_{\text {max }}{ }^{*} \\
\left(\mathrm{~h}^{-1}\right)\end{array}$ & $\begin{array}{c}K_{\mathrm{s}} \\
(\mathrm{mM})\end{array}$ \\
\hline M. formicicum & $\begin{array}{c}\text { Formate } \\
(460)\end{array}$ & 142.4 & 40.1 & 0.18 & $9 \cdot 1$ & 0.034 & 2.8 \\
$M$. barkeri & $\begin{array}{c}\text { Methanol } \\
(115)\end{array}$ & 10.6 & 6.94 & 2.44 & 0.3 & 0.042 & 0.18 \\
\hline
\end{tabular}

* Determined from the rate of wash-out at a dilution rate of $0.05 \mathrm{~h}^{-1}$.

able amounts of $\mathrm{O}_{2}\left[<0.04 \mu \mathrm{mol}(\mathrm{mg} \text { cell-carbon) })^{-1} \mathrm{~h}^{-1}\right]$ in the presence of either formate or methanol.

\section{$\mathrm{O}_{2}$-limited mixed cultures with Methanobacterium formicicum}

(1) Co-culture of $M$. formicicum and $C$. testosteroni. An anoxic formate-limited chemostat culture of $M$. formicicum $\left(D=0.026 \mathrm{~h}^{-1}\right)$ was inoculated with about $150 \mathrm{ml}$ of a L-lactate-grown batch culture of $C$. testosteroni (Fig. 1a). From $t=0$, the culture liquid was supplied with a flow of $\mathrm{N}_{2} / \mathrm{CO}_{2}$ gas containing $\mathrm{O}_{2}$ to a concentration of $0.18 \%(\mathrm{v} / \mathrm{v})$. This gas mixture was supplied at a rate of about $2.51 \mathrm{~h}^{-1}\left(450 \mu \mathrm{M}-\mathrm{O}_{2} \mathrm{~h}^{-1}\right) . \mathrm{O}_{2}$ was consumed at a rate of $138 \pm 19 \mu \mathrm{M} \mathrm{h}^{-1}$ during this initial period of $\mathrm{O}_{2}$-limited growth. Residual L-lactate remained $>17 \mathrm{~mm}$ and the redox-reading and dissolved $\mathrm{O}_{2}$ below $-175 \mathrm{mV}$ and $0.2 \mu \mathrm{M}$, respectively.

A sharp decrease in the rate of methane formation occurred within the first $5 \mathrm{~h}$ of the experiment, probably caused by dilution of the population of $M$. formicicum present in the chemostat (Fig. 1c). During the next 2.5 volume changes $(65 \mathrm{~h})$, methane formation was restored partially but did not reach the initial anoxic value. Both $M$. formicicum and C. testosteroni washed-out, though at a lower rate than the rate of dilution. Even a decrease in the dilution rate (from 0.026 to $0.020 \mathrm{~h}^{-1}$ ) at $t=71 \mathrm{did}$ not prevent a gradual decrease in methane formation.

After $\mathrm{O}_{2}$-limited growth for $165 \mathrm{~h}$ ( 5.3 volume changes) the medium supply was stopped but the introduction of $\mathrm{O}_{2}$ into the culture was maintained at $450 \mu \mathrm{M} \mathrm{h}^{-1}$. The populations of $M$. formicicum and $C$. testosteroni both increased at the expense of the residual formate and L-lactate, respectively, present in the culture vessel, indicating simultaneous growth of both organisms.

(2) Co-culture of M. formicicum and Methylocystis sp. The aerobic methanotrophic bacterium Methylocystis sp. strain $\mathrm{T} 1$ was pre-grown on methane in a batch culture and inoculated into an anoxic formate-limited chemostat $\left(D=0.028 \mathrm{~h}^{-1}, \quad S_{r}^{\text {formate }}=430 \mathrm{mM}\right)$ of $M$. formicicum. Although Methylocystis should be able to grow at the expense of methane produced by $M$. formicicum, the poor affinity for $\mathrm{O}_{2}$ would preclude significant growth on methane (see above) at very low $\mathrm{O}_{2}$-concentrations. Therefore some methanol (initial concentration $57 \mathrm{~mm}$ ) was added to the culture vessel to support $\mathrm{O}_{2}$-limited growth of this bacterium. Gradual introduction of air into the flow-gas resulted in an oxygen supply rate of $400-500 \mu \mathrm{M} \mathrm{h}^{-1}$ and a rate of $\mathrm{O}_{2}$ consumption of $30-50 \mu \mathrm{M} \mathrm{h}^{-1}$. Nevertheless, wash-out of the population of Methylocystis and methanol occurred at a rate equal to the dilution rate, indicating 

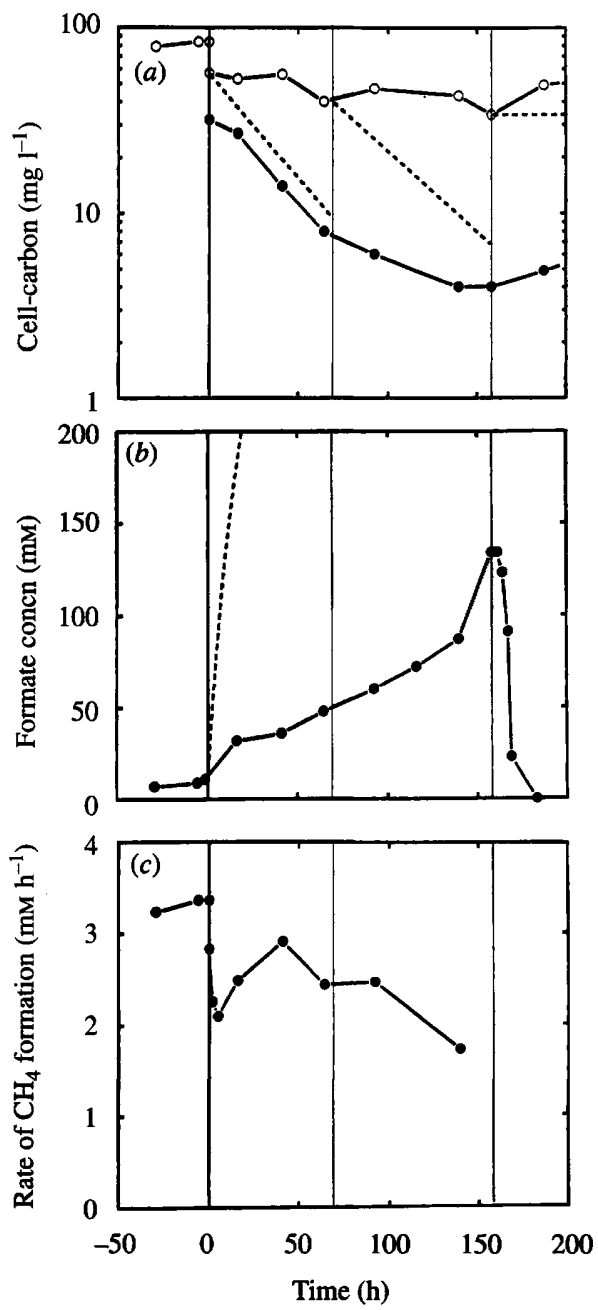

Fig. 1. Time-course of a mixed continuous culture of Methanobacterium formicicum and $C$. testosteroni. $C$. testosteroni was inoculated into a formate-limited chemostat culture $\left(D=0.026 \mathrm{~h}^{-1}, \mathrm{pH} 7.5\right.$, temperature $37^{\circ} \mathrm{C}$ ) of $M$. formicicum at $t=0$. Also at $t=0$, the resulting co-culture containing $57 \mathrm{mg} M$. formicicum cell-carbon $\mathrm{l}^{-1}$ and $32 \mathrm{mg} C$. testosteroni cell-carbon $1^{-1}$ was exposed to limiting amounts of $\mathrm{O}_{2}$ $\left(0 \cdot 18 \%, \mathrm{v} / \mathrm{v}\right.$, in the gas-flow). At $t=71, D$ was reduced from $0.026 \mathrm{~h}^{-1}$ to $0.020 \mathrm{~h}^{-1}$ and at $t=165$ the medium supply was stopped. Carbon and energy sources in the reservoir medium were formate $\left(S_{\mathrm{r}}=\right.$ $460 \mathrm{mM})$ for $M$. formicicum and L-lactate $\left(S_{\mathrm{r}}=20 \mathrm{~mm}\right)$ for $C$. testosteroni. (a) Biomass of the population of $M$. formicicum $(O)$ and C. testosteroni $(\mathbf{O})$; - _ - , rate of wash-out in the absence of growth. (b) Residual formate (O); - absence of consumption. (c) Rate of methane formation (O).

that this bacterium was not able to grow at the expense of methanol (or methane) oxidation under these severely $\mathrm{O}_{2}$-limited conditions.

Growth of $M$. formicicum was also dramatically inhibited in this co-culture with Methylocystis. Under $\mathrm{O}_{2}$-limitation, methane formation was reduced by more than $70 \%$ and accumulation of formate and wash-out of the methanogen occurred at a rate nearly equal to the dilution rate. After 3 volume changes, the redox-reading had increased from about -200 to $-80 \mathrm{mV}$. When strictly anoxic conditions were restored at that moment, wash-out of Methylocystis continued, but growth of $M$. formicicum, formate consumption and methane production were resumed instantaneously.

\section{$\mathrm{O}_{2}$-limited mixed cultures of Methanosarcina barkeri and C. testosteroni}

In a preliminary experiment (not shown), a batch culture of $C$. testosteroni was introduced into an anoxic methanol-limited steady-state culture of $M$. barkeri $\left(D=0.026 \mathrm{~h}^{-1}, \quad S_{\mathrm{r}}^{\text {methanol }}=115 \mathrm{mM}, \quad S_{\mathrm{r}}^{\mathrm{L} \text {-lactate }}=21 \mathrm{mM}\right)$. $\mathrm{O}_{2}(0.7 \%, \mathrm{v} / \mathrm{v})$ was included in the $\mathrm{N}_{2} / \mathrm{CO}_{2}$ gas and supplied at a rate of $260-280 \mu \mathrm{M} \mathrm{h}^{-1}$. Under these conditions, the mixed culture consumed $\mathrm{O}_{2}$ at a rate of 11-13 $\mu \mathrm{M} \mathrm{h}^{-1}$. After $4 \cdot 4$ volume changes $(170 \mathrm{~h})$ following inoculation, the density of $C$. testosteroni had dropped from 19 to $4 \mathrm{mg}$ cell-carbon $\mathrm{l}^{-1}$. However, the density of $M$. barkeri $\left(248-251 \mathrm{mg}\right.$ cell-carbon $\left.\mathrm{l}^{-1}\right)$, the residual methanol concentration $(0.3-0.4 \mathrm{~mm}$ and the rate of methane production $\left(1.85-1.95 \mu \mathrm{M} \mathrm{h}^{-1}\right)$ had not changed significantly within this period, indicating that $M$. barkeri was capable of growth and methane formation under these $\mathrm{O}_{2}$-limited conditions, but that the density of $C$. testosteroni dropped to unacceptably low levels.

The results of a very similar experiment, though with a somewhat higher $\mathrm{O}_{2}$-supply $(2 \%, v / v$, at the same flow-rate) to stimulate growth of $C$. testosteroni are shown in Fig. 2. The biomass of M. barkeri in this mixed culture remained about $10 \%$ lower than in the monoculture. However, the time-course of the change in cellcarbon of $M$. barkeri (Fig. $2 a$ ) clearly showed that after the shift to $\mathrm{O}_{2}$-limited conditions the methanogen grew with a specific growth rate corresponding to the dilution rate of the culture $\left(0.026 \mathrm{~h}^{-1}\right)$ (Fig. $2 d$ ). Yet, methanol consumption appeared slightly less than its supply, resulting in a slow increase in the residual methanol concentration (Fig. 2b).

When the dilution rate of the mixed culture was raised from $0.026 \mathrm{~h}^{-1}$ to $0.039 \mathrm{~h}^{-1}$ at $t=142 \mathrm{~h}$, the population of the methanogen washed-out gradually (Fig. 2a). Nevertheless the specific rates of growth $(\mu)$ and methane production $\left(Q_{\mathrm{CH}_{2}}\right)$, expressed per unit of biomass of $M$. barkeri, increased after this shift to a higher dilution rate.

In these cultures, $C$. testosteroni maintained a population density of about $10 \mathrm{mg} \mathrm{l}^{-1}$ at a dilution rate of $0.026 \mathrm{~h}^{-1}$ and showed a drop to about $6 \mathrm{mg} \mathrm{l}^{-1}$ at $D=$ $0.039 \mathrm{~h}^{-1}$ (Fig. 2a). Residual L-lactate (not shown) remained at a saturating concentration for $C$. testosteroni $\left(>17 \mathrm{mM}\right.$ ) as a consequence of the limited supply of $\mathrm{O}_{2}$. In the mixed cultures of $C$. testosteroni and $M$. barkeri, the redox reading always remained between -150 and 

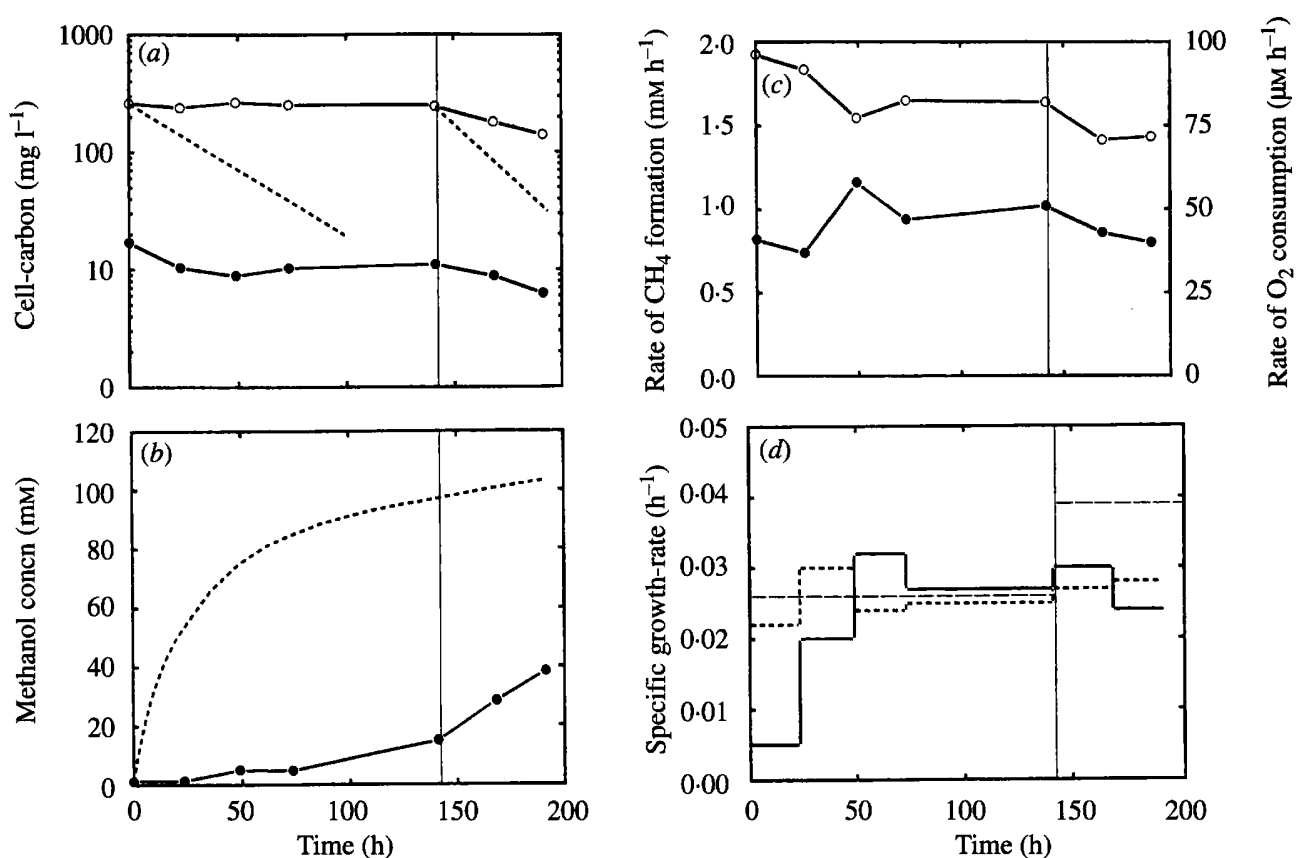

Fig. 2. Time-course of a mixed continuous culture of Methanosarcina barkeri and C. testosteroni. C. testosteroni was inoculated into a methanol-limited chemostat culture $\left(D=0.026 \mathrm{~h}^{-1}, \mathrm{pH} 6.9\right.$, temperature $\left.35^{\circ} \mathrm{C}\right)$ of $M$. barkeri at $t=0$. The co-culture containing $260 \mathrm{mg} \mathrm{M}$. barkeri cell-carbon $\mathrm{1}^{-1}$ and $17 \mathrm{mg} \mathrm{C}$. testosteroni cell-carbon $\mathrm{1}^{-1}$ was subsequently exposed to limiting amounts of $\mathrm{O}_{2}(2 \%$, $\mathrm{v} / \mathrm{v}$, in the gas-flow). At $t=142, D$ was increased from $0.026 \mathrm{~h}^{-1}$ to $0.039 \mathrm{~h}^{-1}$. Carbon and energy sources available in the reservoir medium were methanol $\left(S_{\mathrm{r}}=115 \mathrm{mM}\right)$ for $M$. barkeri and L-lactate $\left(S_{\mathrm{r}}=21 \mathrm{mM}\right)$ for C. testosteroni. $(a)$ Biomass of the population of

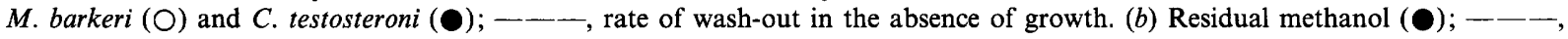
methanol accumulation in the absence of consumption. (c) Rate of methane formation $(O)$ and $\mathrm{O}_{2}$-consumption $(\boldsymbol{O})$. (d) Specific growthrate of the population of $M$. barkeri $(--)$, C. testosteroni $(-)$ and the dilution rate $(---)$ of the mixed culture.

$-250 \mathrm{mV}$, and the dissolved $\mathrm{O}_{2}$-concentration remained below the detection limit of the $\mathrm{O}_{2}$-probe $(<0.2 \mu \mathrm{M})$.

\section{Discussion}

The results presented in this paper show that methanogenic bacteria can be grown in mixed cultures with aerobic bacteria in chemostats, under $\mathrm{O}_{2}$-limiting conditions. Similar results were obtained earlier with cocultures composed of strictly aerobic and anaerobic fermentative or sulphate-reducing bacteria (Chapman et al., 1992; Gerritse et al., 1990, 1992; Gottschal \& Szewzyk, 1985; Ohta et al., 1990; Van der Hoeven \& Gottschal, 1989; Wimpenny \& Abdollahi, 1991).

Most of the growth parameters $\left(K_{\mathrm{s}}, \mu_{\max }\right.$ and cell yield) obtained in continuous cultures of Methanobacterium formicicum and Methanosarcina barkeri with formate or methanol as the limiting substrates, respectively, were similar to those reported in other studies (Chua \& Robinson, 1983; Schauer \& Ferry, 1980; Schauer et al., 1982; Weimer \& Zeikus, 1978).

Real steady-states of mixed cultures of the methanogenic and aerobic bacteria were not obtained. Without exception the introduction of small amounts of $\mathrm{O}_{2}$ led to a decrease in the rate of methane and biomass formation, together with a rise in the residual concentration of the carbon and energy source of the methanogen. Nevertheless, metabolism and growth of $M$. formicicum as well as that of $M$. barkeri were evident in all the mixed cultures tested. The mixed culture of $M$. barkeri and $C$. testosteroni came closest to a true steady-state, followed by $M$. formicicum plus $C$. testosteroni and the combination of $M$. formicicum plus Methylocystis doing less well.

The observation that metabolism of $M$. formicicum was more inhibited in a mixed culture with Methylocystis than with $C$. testosteroni is most likely explained by the considerably ( 5 to 30 times) higher apparent $\mathrm{O}_{2}$-affinity of the latter organism. Particularly with methane as the substrate, the $\mathrm{O}_{2}$-consumption capacity of Methylocystis was relatively low. This suggests that methane monooxygenase, catalysing the initial oxidative step in methane metabolism by methanotrophic bacteria (the oxidation of methane to methanol) limits the rate of $\mathrm{O}_{2}-$ utilization by Methylocystis. Similar observations were reported for Methylosinus trichosporium (Best \& Higgins, 1981; Joergensen, 1985).

Because mixed cultures of $C$. testosteroni and $M$. barkeri were relatively stable and easy to grow, they were analysed in more detail. Although $M$. barkeri could be 
maintained in a seemingly stable $\mathrm{O}_{2}$-limited mixed culture with $C$. testosteroni for more than 8 volume changes $(>8 \mathrm{~d})$, this did not represent truly stable co-existence of the methanogen and the aerobe. Apparently, the $\mathrm{O}_{2}$ affinity of $C$. testosteroni is slightly insufficient to establish a dissolved $\mathrm{O}_{2}$-concentration low enough to allow growth of the methanogen at a rate equal or above the dilution rate of the chemostat.

A major obstacle for the quantification of the inhibitory effect of $\mathrm{O}_{2}$ on the growth of $M$. formicicum and $M$. barkeri is that suppression of their growth-rate took place at $\mathrm{O}_{2}$-concentrations not detectable with the $\mathrm{O}_{2}$-probes in the cultures. The same problem was encountered by Scott et al. (1985) and Lloyd et al. (1989) in determining the effect of $\mathrm{O}_{2}$ on methanogenesis. In well-mixed samples of rumen liquid, anoxic digesters or suspensions of $M$. barkeri, exposed to $\mathrm{O}_{2}$, methanogenesis was consistently inhibited before dissolved $\mathrm{O}_{2}$ became detectable even with a Photobacterium-probe or a membrane-inlet mass spectrometer (detection limits of 30 and $250 \mathrm{nM}$, respectively).

An estimate of the $K_{1}^{\mathrm{O}_{2}}$, the $\mathrm{O}_{2}$-concentration repressing the specific growth rate of the methanogenic bacteria to $\frac{1}{2} \mu_{\max }$, may be obtained indirectly from our results of the mixed cultures with $C$. testosteroni. It is reasonable to assume that under $\mathrm{O}_{2}$-limiting conditions, with saturating concentrations of a carbon and energy source and other nutrients, the specific growth rate $(\mu)$ of a strictly aerobic bacterium depends on the dissolved $\mathrm{O}_{2}$ concentration $\left(\left[\mathrm{O}_{2}\right]\right)$ according to the Monod equation (Owens \& Legan, 1987).

$$
\mu=\mu_{\max } \cdot\left[\mathrm{O}_{2}\right] /\left(K_{\mathrm{s}}+\left[\mathrm{O}_{2}\right]\right)
$$

By further assuming that the half-saturation constant $\left(K_{\mathrm{s}}\right)$ for $\mathrm{O}_{2}$-limited growth of $C$. testosteroni is similar to the apparent $K_{\mathrm{m}}$ for $\mathrm{O}_{2}$-consumption determined respirometrically, it follows that the dissolved $\mathrm{O}_{2}$ concentrations in the co-culture of $M$. barkeri and $C$. testosteroni can be assessed as follows.

$$
\left[\mathrm{O}_{2}\right]=\mu \cdot K_{\mathrm{m}} /\left(\mu_{\max }-\mu\right)
$$

In this equation, $\mu$ represents the specific growth rate of C. testosteroni in the mixed culture, $\mu_{\max }$ is the maximum specific growth rate on L-lactate at saturating $\mathrm{O}_{2}$ and lactate concentrations $\left(0.39 \mathrm{~h}^{-1}\right)$, and $K_{\mathrm{m}}$ is the halfsaturation constant for $\mathrm{O}_{2}$-consumption obtained respirometrically $(0.45 \mu \mathrm{M})$ with $C$. testosteroni grown at $35^{\circ} \mathrm{C}$ in a batch culture on L-lactate. This latter value is close to the apparent $K_{\mathrm{m}}(0.35 \mu \mathrm{M})$ determined previously for this bacterium grown in pure culture on L-lactate in an $\mathrm{O}_{2}$-limited chemostat culture $\left(D=0 \cdot 1 \mathrm{~h}^{-1}\right)$ at $30^{\circ} \mathrm{C}$ (Gerritse et al., 1992).

The dissolved $\mathrm{O}_{2}$-concentrations in the $\mathrm{O}_{2}$-limited cocultures of $C$. testosteroni and M. barkeri thus calculated were in the range 6 to $40 \mathrm{nM}$ using the values for $\mu$ shown in Fig. $2(d)$. In these cultures, the specific growth rate of M. barkeri varied from 0.022 to $0.032 \mathrm{~h}^{-1}$, which is within $50-75 \%$ of the anaerobically determined $\mu_{\max }$ on methanol $\left(0.042 \mathrm{~h}^{-1}\right)$. Consequently, the apparent $K_{\mathrm{i}}^{\mathrm{O}_{2}}$ of $M$. barkeri is presumably slightly higher than $40 \mathrm{nM}$ (about 50-60 nM). Similar calculations for the mixed culture of C. testosteroni with $M$. formicicum suggest that this latter methanogen is less tolerant to $\mathrm{O}_{2}$ than $M$. barkeri, with a $K_{\mathrm{i}}^{\mathrm{O}_{2}}$ of about $10-20 \mathrm{nM}$. This difference in $\mathrm{O}_{2}$-sensitivity could be based on the ability of $M$. barkeri to form cellclusters which may help to minimize the exposure to $\mathrm{O}_{2}$ of cells present in the interior of such cell-aggregates (Kiener \& Leisinger, 1983). In our mixed-culture experiments, cell-aggregates of $M$. barkeri were composed of about 5-50 cells. Obviously, since these inhibition constants are estimates obtained in an indirect way, they should be interpreted cautiously and regarded as maximum values.

It is of interest to note that these experiments clearly indicate that the level of $\mathrm{O}_{2}$-tolerance of the methanogenic bacteria used in this study is in the same order of magnitude as the dissolved $\mathrm{O}_{2}$-concentrations maintained under $\mathrm{O}_{2}$-limitation by $C$. testosteroni. The fact that such metabolically diverse organisms as strict aerobes and methanogens can thrive simultaneously in the same habitat strongly suggests the possibility of a very direct coupling of the metabolic capacities of these bacteria. This not only influences our views on the flow of carbon substrates in natural low- $\mathrm{O}_{2}$ environments but it may also prove particularly useful for the development of biological purification systems (Gerritse et al., 1992).

This investigation was supported by the Netherlands Integrated Soil Research Project. We thank Dr E. Raemakers-Franken and Dr K. Takeda for their kind gift of Methanobacterium formicicum and Methylocystis sp., respectively.

\section{References}

Alldredge, A. L. \& Cohen, Y. (1987). Can microscale chemical patches persist in the sea? Microelectrode study of marine snow, faecal pellets. Science 235, 689-691.

BEST, D. J. \& HigGrNS, I. J. (1981). Methane-oxidizing activity and membrane morphology in a methanol-grown obligate methanotroph, Methylosinus trichosporum OB3b. Journal of General Microbiology 125, 73-84.

Chapman, S. J., Veal, D. A. \& Lynch, J. M. (1992). Effect of oxygen concentration on dinitrogen fixation and volatile fatty acid production by Clostridium butyricum growing in association with fungi on cellulose and on wheat straw. Journal of Applied Bacteriology 72, 9-15.

ChUA, H. B. \& Robinson, J. P. (1983). Formate-limited growth of Methanobacterium formicicum in steady-state cultures. Archives of Microbiology 135, 158-160.

GERRITSE, J. \& GoTTSCHAL, J. C. (1992). Mineralization of the herbicide 2,3,6-trichlorobenzoic acid by a co-culture of anaerobic and aerobic bacteria. FEMS Microbiology Ecology 101, 89-98.

GerRITSE, J., SChUT, F. \& GotTSChal, J. C. (1990). Mixed chemostat 
cultures of obligately aerobic and fermentative or methanogenic bacteria grown under oxygen-limiting conditions. FEMS Microbiology Letters 66, 87-94.

GerRITSE, J., SchUt, F. \& GotTsChal, J. C. (1992). Modelling of mixed chemostat cultures of an aerobic bacterium, Comamonas testosteroni, and an anaerobic bacterium, Veillonella alcalescens: comparison with experimental data. Applied and Environmental Microbiology 58, 1466-1476.

GotTsChal, J. C. \& SzewzYK, R. (1985). Growth of a facultative anaerobe under oxygen-limiting conditions in pure culture and in co-culture with a sulfate-reducing bacterium. FEMS Microbiology Ecology 31, 159-170.

Heisthuisen, J. H. F. G. \& Hansen, T. A. (1986). Interspecies hydrogen transfer in co-cultures of methanol utilizing acidogens and sulfate-reducing or methanogenic bacteria. FEMS Microbiology Ecology 38, 57-64.

JOERGENSEN, L. (1985). Methane oxidation by Methylosinus trichosporium measured by membrane-inlet mass spectrometry. In Microbial Gas Metabolism, pp. 287-294. Edited by R. K. Poole \& C. S. Dow. London: Academic Press.

Jones, W. J., PAYNTER, M. J. B. \& GUPTA, R. (1983). Characterization of Methanoccus maripaludis sp. nov., a new methanogen isolated from salt marsh sediment. Archives of Microbiology 135, 91-97.

Kengen, S. W. M., Von den HoFf, H. W., KeltJens, J. T., VAN DEN DRIFT, C. \& VoGELs, G. D. (1991). Hydrolysis and reduction of factor 390 by cell extracts of Methanobacterium thermoautotrophicum (strain $\Delta \mathrm{H}$ ). Journal of Bacteriology 173, 2283-2288.

KIRBY, T. W., LANCASTER, J. R. \& FrIDOVICH, I. (1981). Isolation and characterization of the iron-containing superoxide dismutase of Methanobacterium bryantii. Archives of Biochemistry and Biophysics 210, 140-148.

KIENER, A. \& LEISINGER, T. (1983). Oxygen sensitivity of methanogenic bacteria. Systematic and Applied Microbiology 4, 305-312.

KiENER, A., ORME-JOHnsON, W. H. \& WALSH, C. T. (1988). Reversible conversion of coenzyme $\mathrm{F}_{420}$ to the 8-OH-AMP and 8-OH-GMP esters, $F_{390}-A$ and $F_{390}-G$, on oxygen exposure and reestablishment of anaerobiosis in Methanobacterium thermoautotrophicum. Archives of Microbiology 150, 249-253.

LANG, E. \& LANG, H. (1972). Spezifische Farbreaction zum direkten Nachweis der Ameisensäure. Zeitung Analytische Chemie 260, 8-10.

Lloyd, D., DAVIES, J. P. \& BODDY, L. (1986). Mass spectrometry as an ecological tool for in situ measurement of dissolved gases in sediment systems. FEMS Microbiology Ecology 38, 11-17.

Lloyd, D., Hillman, K., Yarlett, N. \& Williams, A. G. (1989). Hydrogen production by rumen holotrich protozoa: effects of oxygen and implications for metabolic control by in situ conditions. Journal of Protozoology 36, 205-213.

MAH, R. A. \& SMITH, M. R. (1981). The methanogenic bacteria. In The Prokaryotes, pp. 948-977. Edited by M. P. Starr, H. Stolp, H. G. Trüper, A. Balows \& H. G. Schlegel. Heidelberg: Springer Verlag.

MORRIS, J. G. (1976). Fifth Stenhouse-Williams Memorial Lecture. Oxygen and the obligate anaerobe. Journal of Applied Bacteriology 40, 229-244.

NanNinga, H. J. \& GotTschal, J. C. (1985). Amino acid fermentation and hydrogen transfer in mixed cultures. FEMS Microbiology Ecology 31, 261-269.

Ohta, H., Gottschal, J. C., Fukui, K. \& Kato, K. (1990).
Interrelationships between Wolinella recta and Streptococcus sanguis in mixed continuous cultures. Microbial Ecology in Health and Disease 3, 237-244.

OREMLAND, R. S. (1988). Biogeochemistry of methanogenic bacteria. In Biology of Anaerobic Microorganisms, pp. 641-705. Edited by A. J. B. Zehnder. New York: John Wiley.

Owens, J. D. \& Legan, J. D. (1987). Determination of the Monod substrate saturation constant for microbial growth. FEMS Microbiology Reviews 46, 419-432.

Patel, G. B., Roth, L. A. \& AgNew, B. J. (1984). Death rates of obligate anaerobes exposed to oxygen and the effect of media prereduction on cell viability. Canadian Journal of Microbiology 30, 228-235.

Roberton, A. M. \& Wolfe, R. S. (1970). Adenosine triphosphate pools in Methanobacterium. Journal of Bacteriology 102, 43-51.

RUDD, J. W. M. \& TAYLOR, C. D. (1980). Methane cycling in aquatic environments. Advances in Aquatic Microbiology 2, 77-149.

Schauer, N. L., Brown, D. P. \& Ferry, J. G. (1982). Kinetics of formate metabolism in Methanobacterium formicicum and Methanospirillum hungatei. Applied and Environmental Microbiology 44, 549-554.

SCHAUER, N. L. \& FERRY, J. G. (1980). Metabolism of formate in Methanobacterium formicicum. Journal of Bacteriology. Journal of Bacteriology 142, 800-807.

SChÖNheit, P., KeWeloh, H. \& ThaueR, R. K. (1981). Factor $\mathrm{F}_{420}$ degradation in Methanobacterium thermoautotrophicum during exposure to oxygen. FEMS Microbiology Letters 12, 347-349.

SCotT, R. I., Williams, N. G., Whitemore, T. N. \& Lloyd, D. (1985). Mass spectrometric determinations of the effect of oxygen on methanogenesis: inhibition or stimulation? In Microbial Gas Metabolism, pp. 263-270. Edited by R. K. Poole \& C. S. Dow. London: Academic Press.

SIEBURTH, J. M. (1987). Contrary habitats for redox-specific processes: methanogenesis in oxic waters and oxidation in anoxic waters. In Microbes in the Sea, pp. 11-38. Edited by M. A. Sleigh. Chichester: Ellis Horwood.

Smith, P. H. \& Hungate, R. E. (1958). Isolation and characterization of Methanobacterium ruminatium n. sp. Journal of Bacteriology 75, 713-718.

TAKEDA, K. (1988). Characteristics of a nitrogen-fixing methanotroph, Methyloycystis T-1. Anthonie van Leeuwenhoek 54, 521-534.

VAN DER HoEven, H. S. \& GotTSChal, J. C. (1989). Growth of mixed cultures of Actinomyces viscosus and Streptococcus mutans under dual limitation of glucose and oxygen. FEMS Microbiology Ecology 62, 275-284.

Vogels, G. D., KeltJens, J. T. \& VAN DER DRIfT, C. (1988) Biochemistry of methane production. In Biology of Anaerobic Microorganisms, pp. 707-770. Edited by A. J. B. Zehnder. New York: John Wiley.

Weimer, P. J. \& Zeikus, J. G. (1978). One carbon metabolism in methanogenic bacteria: cellular characterization and growth of Methanosarcina barkeri. Archives of Microbiology 119, 49-57.

WIMPENNY, J. W. T. (1981). Spatial order in microbial ecosystems. Biological Reviews 56, 295-342.

WimpenNy, J. W. T. \& Abdollahi, H. (1991). Growth of mixed cultures of Paracoccus denitrificans and Desulfovibrio desulfuricans in homogeneous and heterogeneous culture systems. Microbial Ecology 22, 1-13.

Zehnder, A. J. B. \& Wuhrmann, K. (1977). Physiology of a Methanobacterium strain AZ. Archives of Microbiology 111, 199-205. 